\title{
BIBECHANA
}

A Multidisciplinary Journal of Science, Technology and Mathematics

ISSN 2091-0762 (online)

Journal homepage: http://nepjol.info/index.php/BIBECHANA

\section{A study on the surface deterioration of home made halide sensors}

\author{
A. Rajbhandari (Nyachhyon)*, K. Manandhar, R.R. Pradhananga \\ Central Department of Chemistry, Tribhuvan University, Kathmandu, Nepal \\ *Corresponding author: Email: armila3@yahoo.com \\ Article history: Received 25 November, 2011; Accepted 2 July, 2012
}

\begin{abstract}
Home made halide sensors based on silver sulphide-silver halide have been prepared and successfully employed for the determination of iodide, bromide and chlorides ions in solutions. These ion sensors showed a Nernstian response in the concentration range of $10^{-1}$ to $10^{-7} \mathrm{M}$ for iodide ions, $10^{-6} \mathrm{M}$ for bromide ions, and $10^{-5} \mathrm{M}$ for chloride ions. The response time of these sensors was $<1 \mathrm{~min}$. We have found that the iodide ion sensor can selectively detect iodide ions in presence of chloride and bromide ions. However, sensing performance of the bromide and chloride sensors are largely interfered by the presence of iodide ions. Surface study showed that surface deterioration of membrane was caused by the solutions containing interfering ions and its regular use, particularly in dilute solutions.
\end{abstract}

Keywords: Electrochemical sensors; Nernstian response; Selectivity co-efficient, Surface deterioration

\section{Introduction}

Halide sensors are ion selective electrodes (ISEs) that provide a convenient and quick analytical procedure for the estimation of particular ions in solution. Because of the simplicity, low cost of fabrication and operation, accuracy, applicability to extreme conditions and timeliness, they are renowned as novel analytical tools [1] and are suitable for diverse fields of analysis such as pharmaceutical analysis, plant and vegetable analysis, seawater analysis. Ion selective electrodes of different types are reported in the literature [1]. Silver sulphide-based all solid state ion selective electrodes [2-7] are one of the promising electrodes as these are free from the problem of leakage and evaporation of internal electrolytes and stable among other ISEs. But the Nernstian response of electrode was affected after using prolonged period of time. The reproducibility and response time was adversely affected. In this study, a simple, low cost iodide, bromide and chloride ion sensors have been developed from polycrystalline silver sulphide-silver halide materials. The response behavior and selectivity of fabricated electrodes were studied. Potentiometric titrations were performed to evaluate the applicability of electrodes. Finally, the surface deterioration of the membrane was investigated to study the reproducibility and response time.

\section{Experimental Section}

\section{Materials and Methods}

All the reagents $\left(\mathrm{AgNO}_{3}, \mathrm{KI}, \mathrm{KBr}, \mathrm{KCl}, \mathrm{KNO}_{3}\right)$ were of analytical grade. All the solutions were prepared in distilled water. All potentiometric measurements on electrodes were performed with OSAW digital 
potentiometer, India. The silver/silver chloride electrode (SSE) was used as a standard reference electrode. All the measurements were carried out in constant stirring conditions at $25^{\circ} \mathrm{C}$.

\section{Fabrication of electrodes}

Equi-molar mixture of aqueous solution of $\mathrm{Na}_{2} \mathrm{~S}$ and $\mathrm{KX}(\mathrm{X}=\mathrm{I}, \mathrm{Br}, \mathrm{Cl})$ were taken in separately and silver nitrate solution was added. After shaking, co-precipitate of $\mathrm{Ag}_{2} \mathrm{~S} / \mathrm{AgI}, \mathrm{Ag}_{2} \mathrm{~S} / \mathrm{AgBr}, \mathrm{Ag}_{2} \mathrm{~S} / \mathrm{AgCl}$ were obtained and were filtered, dried, grinded into fine powders. Then the pellets were prepared using $\mathrm{KBr}$ pellet making machine. Details of preparation and characterization of pellets are given elsewhere [3]. Thus prepared $\mathrm{Ag}_{2} \mathrm{~S}-\mathrm{AgX}$ pellets were connected with silver back having a copper wire and adhered into a polyethylene tube with araldite. The wire was about 6 inches long for electrical conduction. The detail procedure of fabrication of electrode is given elsewhere [3-5]. The electrodewas then abraded using silicon carbide paper from 1000-2000 grit size. The electrode was washed thoroughly with distilled water and then sonicated for 15 minutes. Electrodes were immersed for 15 minutes in solution of respective ions before use.

The response of the $\mathrm{Ag}_{2} \mathrm{~S} / \mathrm{AgX}$ electrodes for respective $\mathrm{X}(\mathrm{X}=\mathrm{I}, \mathrm{Br}, \mathrm{Cl})$ ions was measured by standard addition technique at constant ionic strength $(\mu=0.1 \mathrm{M})$ using $0.1 \mathrm{M} \mathrm{KNO}_{3}$ as background electrolyte. Dynamic response of electrodes was obtained by noting the cell emf at the interval of 30 seconds till equilibrium potential was obtained. Selectivity coefficient values were obtained by fixed interference method [8]. Potentiometric titrations of $\mathrm{KX}(\mathrm{X}=\mathrm{I}, \mathrm{Br}, \mathrm{Cl})$ by silver nitrate were carried out. Surface study of membrane pellets of $\mathrm{Ag}_{2} \mathrm{~S}-\mathrm{AgI}, \mathrm{Ag}_{2} \mathrm{~S}-\mathrm{AgBr}$ and $\mathrm{Ag}_{2} \mathrm{~S}-\mathrm{AgCl}$ were studied by visual observation. A digital photo graphs were taken before and after immersion of electrode in solutions containing interfering ions and in dilute solutions.

\section{Results and Discussion}

\section{Potentiometric response of the $\mathrm{Ag}_{2} \mathrm{~S}-\mathrm{AgI}$ to iodide ions}

The response of $\mathrm{Ag}_{2} \mathrm{~S}-\mathrm{AgI}$ electrode to iodide ion was investigated by measuring cell potential (EMF) of the $\mathrm{Ag}_{2} \mathrm{~S}-\mathrm{AgI}$ electrode coupled with a saturated silver-silver chloride reference electrode. The EMF was measured at $25^{\circ} \mathrm{C}$ at $10^{-1}$ to $10^{-7} \mathrm{M}\left[\mathrm{I}^{-}\right]$ion concentrations. The ionic strength was maintained by using 0.1 $\mathrm{M} \mathrm{KNO}_{3}$. The result is shown in Fig 1 (curve c).

The cell potential showed a linear decrease in the EMF vs. $-\log \left[\mathrm{I}^{-}\right]$plot over a wide concentration range of $10^{-1}$ to $10^{-7} \mathrm{M}$. Symbols are the data points and dotted line represents the line of best fit. From the best fit in the linear region, the slope was calculated to be $58.7 \mathrm{mV}$, indicating that the electrode shows Nernstian behavior. From Fig.1 (curve c), the EMF of cell can be expressed by the equation below for the concentration range $10^{-1} \mathrm{M}$ to $10^{-7} \mathrm{M}$.

$$
\mathrm{E}=-398-58.7 \log \left[\mathrm{I}^{-}\right] \ldots \ldots \ldots \ldots
$$

\section{Potentiometric response of the $\mathrm{Ag}_{2} \mathrm{~S}-\mathrm{AgBr}$ to bromide ions}

The response of $\mathrm{Ag}_{2} \mathrm{~S}-\mathrm{AgBr}$ electrode to bromide ion was investigated by measuring cell potential (EMF) of the $\mathrm{Ag}_{2} \mathrm{~S}-\mathrm{AgBr}$ electrode coupled with a saturated silver-silver chloride reference electrode. The EMF of the cell was measured at $25^{\circ} \mathrm{C}$ at $10^{-1}$ to $10^{-6} \mathrm{M} \mathrm{Br}^{-}$ion concentrations while maintaining the ionic strength at $0.1 \mathrm{M}$ using $\mathrm{KNO}_{3}$. The result is shown in Fig. 1 (curve b).

A linear response with $58 \mathrm{mV}$ per concentration decade was obtained in the concentration range from $10^{-1} \mathrm{M}$ to $10^{-6} \mathrm{M}$ (Fig.1 curve b). From Fig 1 (curve b), the EMF of cell can be expressed by following equation.

$$
\mathrm{E}=-175-58 \log \left[\mathrm{Br}^{-}\right] \ldots \ldots \ldots \ldots
$$




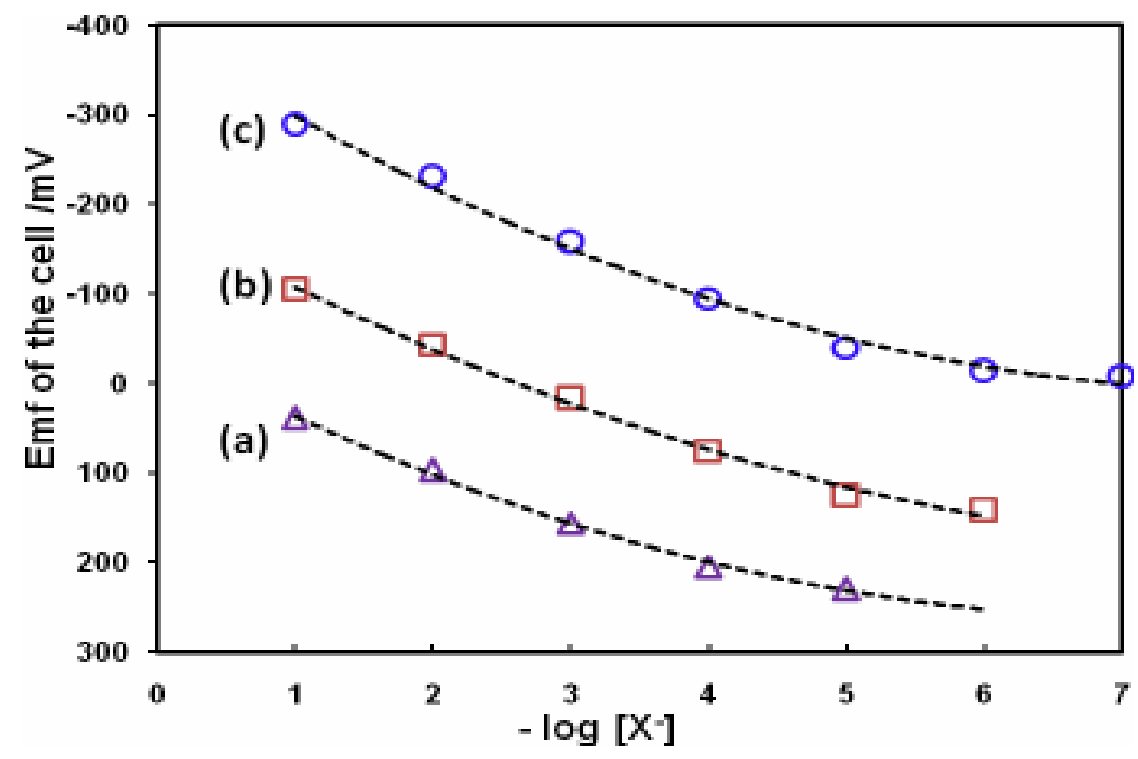

Fig.1: Plot of the cell EMF against $-\log \left[\mathrm{X}^{-}\right]$. Symbols are the data poinst and dotted line represents the line of best fit. Curve a indicates cell EMF as a function of $-\log [\mathrm{Cl}-]$, Curve $b$ indicates cell EMF as a function of $-\log \left[\mathrm{Br}^{-}\right]$and Curve $\mathrm{c}$ indicates cell EMF as a function of $-\log \left[\mathrm{I}^{-}\right]$.

\section{Potentiometric response of the $\mathrm{Ag}_{2} \mathrm{~S}-\mathrm{AgCl}$ to chloride ions}

The EMF of the cell in $\mathrm{mV}$ with $\mathrm{Ag}_{2} \mathrm{~S}-\mathrm{AgCl}$ membrane electrode coupled with a saturated silver-silver chloride reference electrode is plotted against $-\log \left[\mathrm{Cl}^{-}\right]$which is shown in Fig. 1(curve a).

A linear curve was obtained over a concentration range of $10^{-1} \mathrm{M}$ to $10^{-5} \mathrm{M}$. From the best fit in the linear region, the slope was calculated to be $56 \mathrm{mV}$. This means the cell potential changes by $56 \mathrm{mV}$ per decade change in $\mathrm{Cl}^{-}$ion concentration at $25^{\circ} \mathrm{C}$ indicating the Nernstian behavior of fabricated electrode. From Fig. 1 (curve a), the EMF of cell follows the following equation.

$$
\mathrm{E}=-27-56 \log \left[\mathrm{Cl}^{-}\right] \ldots \ldots \ldots \ldots
$$

\section{Dynamic response}

The dynamic response of $\mathrm{Ag}_{2} \mathrm{~S}-\mathrm{AgI}, \mathrm{Ag}_{2} \mathrm{~S}-\mathrm{AgBr}, \mathrm{Ag}_{2} \mathrm{~S}-\mathrm{AgCl}$ electrodes were measured in $10^{-3} \mathrm{M}$ concentration of respective ions at 1 minute interval of time. The results are shown in Fig 2 . The stable potential was obtained within 1 minute indicating that the equilibrium was established very fast. In Fig. 2 (curve c) shows the dynamic response curve for $\mathrm{Ag}_{2} \mathrm{~S}-\mathrm{AgI}$, while Fig. 2 (curve b) and Fig. 1 (curve a) for $\mathrm{Ag}_{2} \mathrm{~S}-\mathrm{AgBr}, \mathrm{Ag}_{2} \mathrm{~S}-\mathrm{AgCl}$ electrodes respectively.

\section{Selectivity coefficient}

The potentiometric selectivity coefficient indicates the extent to which a foreign ion B interferes with the response of the electrode to its primary ion A. The potentiometric selectivity coefficients $K_{A, B}^{p o t}$ for the suggested electrodes were measured by fixed solution method [8]. The value of $K^{\text {pot }}{ }_{A, B}$ is defined by the modified Nickolsky-Eisenman equation (Eq.4) [8].The smaller the value of $K_{A, B}^{p o t}$ the greater the electrode's preference for the principal ion, A.

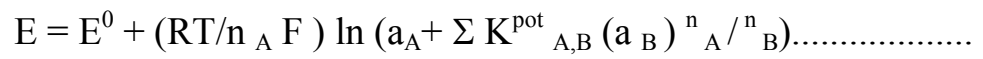




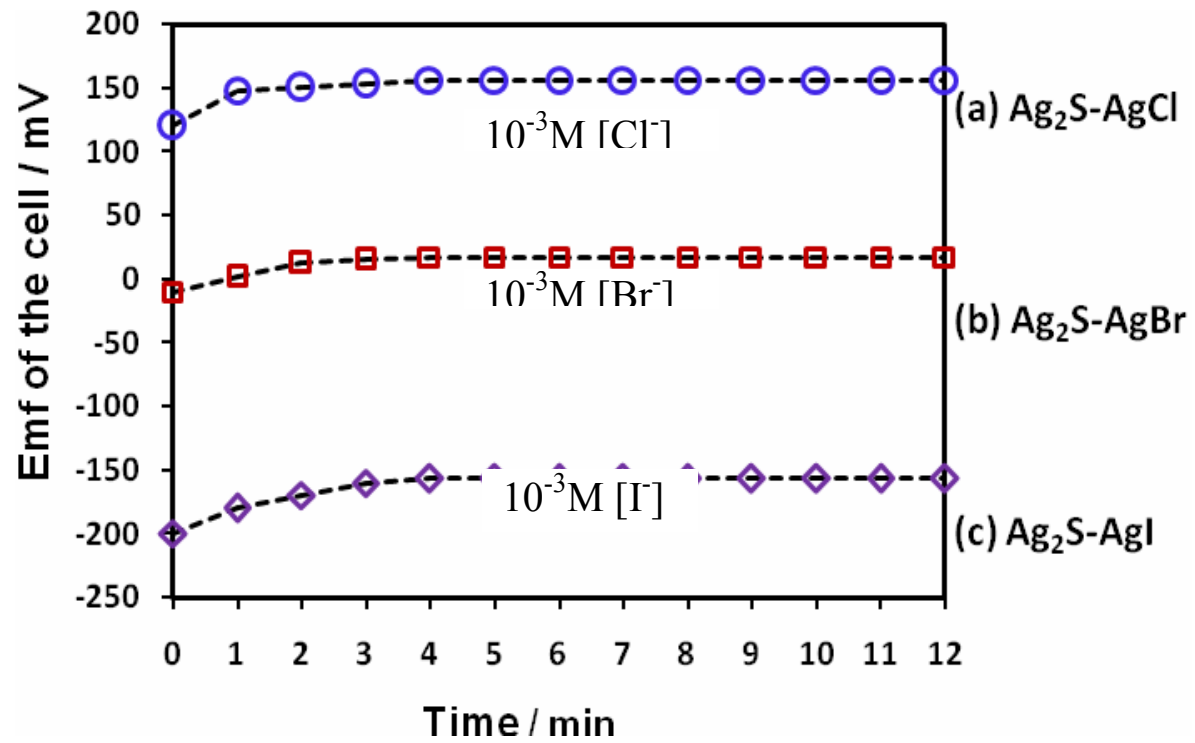

Fig. 2: Dynamic response curve of (a) $\mathrm{Ag}_{2} \mathrm{~S}-\mathrm{AgCl}$ electrode, (b) $\mathrm{Ag}_{2} \mathrm{~S}-\mathrm{AgBr}$ electrode, (c) $\mathrm{Ag}_{2} \mathrm{~S}-\mathrm{AgI}$ electrode.

Where $a_{A}$ and $a_{B}$ are the activities of main and interfering ions having charges $n_{A}$ and $n_{B}$ respectively, $\mathrm{E}^{0}$ is standard potential of the electrode and $K_{A, B}^{p o t}$ is the selectivity coefficient which describes the relative sensitivity of determinant ion. In the present study, fixed solution method [8] was used to determine the selectivity of $\mathrm{Ag}_{2} \mathrm{~S}-\mathrm{AgI}$ electrode containing iodide ion with $\mathrm{Br}^{-}, \mathrm{Cl}^{-}$ions as interfering ions. In this method, the potential of cell comprising an ion selective electrode and reference electrode is measured with solutions of constant level of interfering ions, $\left(\mathrm{Br}^{-}, \mathrm{Cl}^{-}\right)$and varying activity of primary ion $\left(\mathrm{I}^{-}\right)$. Similarly, selectivity of $\mathrm{Ag}_{2} \mathrm{~S}-\mathrm{AgBr}$ electrode towards $\mathrm{I}^{-}$and $\mathrm{Cl}^{-}$ions and selectivity of $\mathrm{Ag}_{2} \mathrm{~S}-\mathrm{AgCl}$ electrode towards $\mathrm{I}^{-}$and $\mathrm{Br}^{-}$ions were also studied using fixed solution method. The results obtained are tabulated in Table 1. These results showed that iodide electrodes are not affected by bromide and chloride ions where as bromide and chloride electrodes are affected by iodide ions which is according to following surface reaction [9]

$$
\mathrm{C}^{+} \mathrm{A}^{-}(\mathrm{s}, \mathrm{membrane})+\mathrm{J}^{-}(\mathrm{aq})=\mathrm{C}^{+} \mathrm{J}^{-}(\mathrm{s}, \text { surface })+\mathrm{A}^{+}(\mathrm{aq}) \ldots \ldots \ldots \ldots
$$

( where, $\mathrm{C}^{+}$is cation and $\mathrm{A}^{-}$is anion in membrane and $\mathrm{J}^{-}$is interfering ion) and the relative magnitude of the interference depend upon the relative solubilities of the solids.

Table 1: Selectivity Coefficient values of respective electrodes.

\begin{tabular}{|c|c|c|c|}
\hline Electrode & $\begin{array}{c}\text { Primary } \\
\text { ion }\end{array}$ & $\begin{array}{c}\text { Interfering } \\
\text { ion }\end{array}$ & $\mathrm{K}^{\text {pot }}{ }_{\mathrm{A}, \mathrm{B}}$ \\
\hline \multirow{2}{*}{$\mathrm{Ag}_{2} \mathrm{~S}-\mathrm{AgI}$} & \multirow{2}{*}{$\mathrm{I}^{-}$} & $\mathrm{Br}^{-}$ & $7.94 \times 10^{-3}$ \\
\cline { 3 - 4 } $\mathrm{Ag}_{2} \mathrm{~S}-\mathrm{AgBr}$ & \multirow{2}{*}{$\mathrm{Br}^{-}$} & $\mathrm{Cl}^{-}$ & $1.77 \times 10^{-2}$ \\
\cline { 3 - 4 } $\mathrm{Ag}_{2} \mathrm{~S}-\mathrm{AgCl}$ & \multirow{2}{*}{$\mathrm{Cl}^{-}$} & $\mathrm{Cl}^{-}$ & 3.98 \\
\cline { 3 - 4 } & & $\mathrm{I}^{-}$ & 48.9 \\
\hline
\end{tabular}




\section{Potentiometric titration}

To test the usefulness of laboratory prepared iodide, bromide and chloride electrodes as an indicator electrode, potentiometric titrations of $\mathrm{KI}$ with $\mathrm{AgNO}_{3}, \mathrm{KBr}$ with $\mathrm{AgNO}_{3}$ and $\mathrm{KCl}$ with $\mathrm{AgNO}_{3}$ were carried out by respective electrodes. A potentiometric titration curve of $1 \times 10^{-2} \mathrm{M}$ potassium iodide with $1 \times 10^{-1} \mathrm{M}$ silver nitrate solution is shown in Fig. 3. Similar titration curves of potassium bromide with silver nitrate and potassium chloride with silver nitrate were observed ( curves are not shown). A clear inflation point can be observed in the titration curve from which one can conclude that the present electrode can be utilized as an indicator electrode for respective ion.

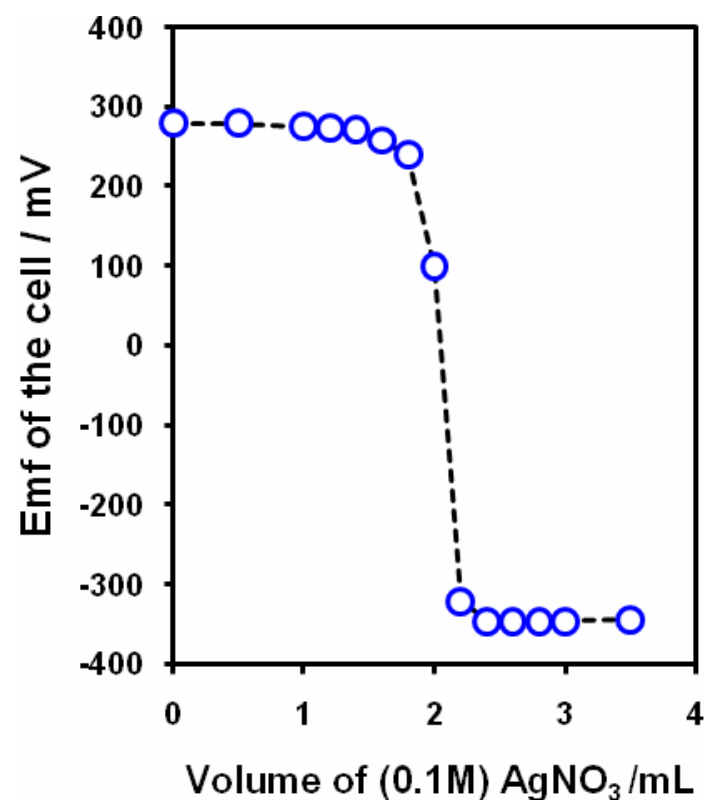

Fig.3: Potentiometric titration $20 \mathrm{~mL}$ of $1 \times 10^{-2} \mathrm{M}$ potassium iodide with $1 \times 10^{-1} \mathrm{M}$ silver nitrate.

\section{Surface study of the membrane}

Surface of membrane is one of the important parameter to study the better performance of electrode. In this study, surface deterioration of membrane of electrodes were investigated by visual observation of surface of membrane. A digital photograph of membrane were taken before and after immersing the electrode in solutions having interfering ions and in dilute solution of its determinant ion. In Fig.4 (a,b,c) digital pictures of $\mathrm{Ag}_{2} \mathrm{~S}-\mathrm{AgCl}$ electrode are shown before and after immersing the electrode in $10^{-3} \mathrm{M} \mathrm{KCl}$ solutions having interfering ions namely iodide and bromide at $10^{-3} \mathrm{M}$ concentration and storing the electrode in $10^{-7} \mathrm{M} \mathrm{KCl}$ for 48 hours. Then the response behavior was examined and found that results are not reproducible and increase of response time. Fig. 4a showed that surface of the membrane is found to be smooth and fine. In Fig. $\mathbf{4 b}$, it was clearly observed that surface is tanned due to formation of surface film of precipitate of $\mathrm{AgI}$ and $\mathrm{AgBr}$ as $\mathrm{AgI}$ and $\mathrm{AgBr}$ has low solubility values of $\left(8.3 \times 10^{-16}\right)$ and $\left(5 \times 10^{-}\right.$ ${ }^{13}$ ) respectively. The selectivity coefficient values were also indicating the formation of $\mathrm{AgI}$ and $\mathrm{AgBr}$ as equilibrium of reaction lies to right side in equation (5). In Fig. 4c, a pitted surface can be clearly seen when it was storing in dilute solution of $10^{-7} \mathrm{M} \mathrm{KCl}$ for 48 hours. It is obvious that the dissolution of membrane surface was occurred. It may be due to the higher value of solubility of $\mathrm{AgCl}\left(1.7 \times 10^{-10}\right)$. It is unfortunate that dissolution of membrane is not uniform, then surface became very rough having small pitted holes. As increase in number of pitted holes occur, the reproducibility in response behavior was adversely affected. Small volumes of solution may get trapped in the cavities and transferred from one 
sample to next sample during EMF measurement. Similar pictures were obtained in $\mathrm{Ag}_{2} \mathrm{~S}-\mathrm{AgBr}$ electrode whereas in $\mathrm{Ag}_{2} \mathrm{~S}-\mathrm{AgI}$ electrode, surface got tanned due to formation of $\mathrm{KAg}[\mathrm{I}]_{2}$ complex.
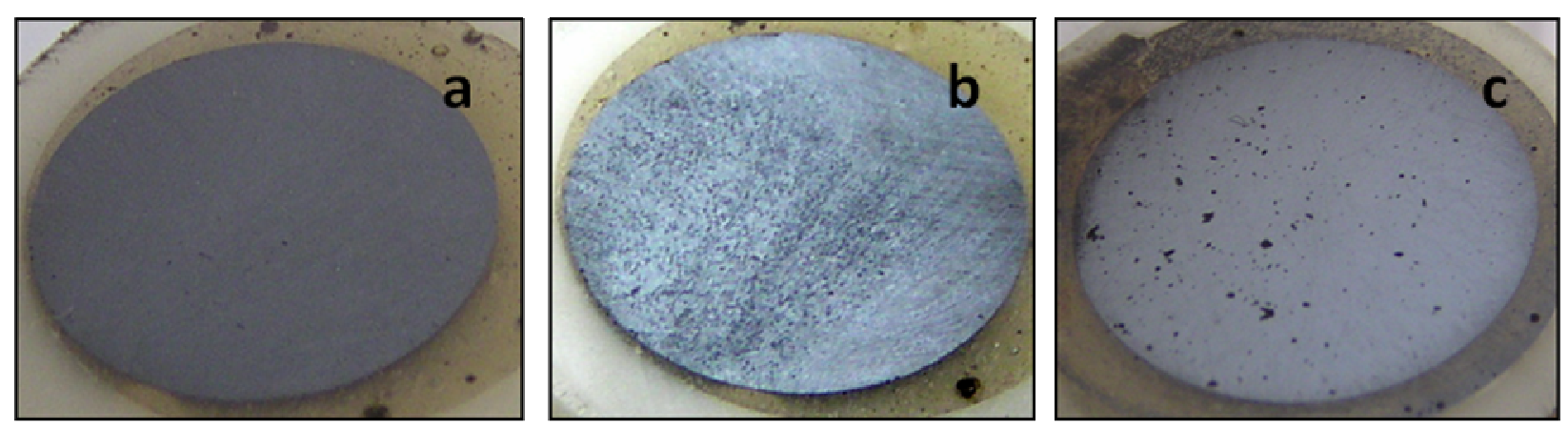

Fig. 4: (a) surface of $\mathrm{Ag}_{2} \mathrm{~S}-\mathrm{AgCl}$ membrane pellet before immersing in $\mathrm{KCl}$ solution, (b) surface of $\mathrm{Ag}_{2} \mathrm{~S}-\mathrm{AgCl}$ membrane pellet after immersing in $10^{-3} \mathrm{M} \mathrm{KCl}$ having $10^{-3} \mathrm{M}\left[\mathrm{I}^{-}\right]$and $\left[\mathrm{Br}^{-}\right]$solution, (c) surface of $\mathrm{Ag}_{2} \mathrm{~S}-\mathrm{AgCl}$ membrane pellet after storing in $10^{-7} \mathrm{M} \mathrm{KCl}$ for 48 hours.

\section{Conclusions}

Home made halide sensors sensitive for iodide; bromide and chloride ions prepared and revealed a Nernstian response over a wide concentration range, fast response time. The selectivity coefficient values showed that iodide electrodes are not interfered by chloride and bromide ions which is in agreement with solubility values. These sensors are found to be applicable as an indicator electrode for respective ions. The surface deterioration of electrode mainly depends upon the regular use in solutions having interfering ions and dilute solutions of determinant ion.

\section{Acknowledgements}

We gratefully acknowledge the support of Institute of Science and Technology, Tribhuvan University, and Nepal Academy of Science and Technology, Nepal for this research work.

\section{References}

[1] P.L. Bailey, Analysis with Ion Selective Electrodes, Heyden and Son, London (1976).

[2] R.R. Pradhananga, and L.K. Shrestha: Trans MRS-J., 33(2008)345.

[3] A. Rajbhandari (Nyachhyon), A.P. Yadav, K. Manandhar and R.R. Pradhananga, Talanta, 82 (2010) 1448.

[4] R.R. Pradhananga and A. Rajbhandari (Nyachhyon): Scientific World, 6 (2008) 33.

[5] A. Rajbhandari (Nyachhyon), A.P. Yadav, K., Manandhar and R.R. Pradhananga, Scientific World, 7 (2009) 19.

[6] A. Rajbhandari (Nyachhyon), A.P. Yadav, K., Manandhar and R.R. Pradhananga, Advanced Materials Research, 117 (2010) 93.

[7] A. Rajbhandari (Nyachhyon), A.P. Yadav, K.. Manandhar and R.R. Pradhananga, Advanced Materials Research, 17 (2010) 7.

[8] Y. Umezawa, P. Buhlmann, K. Umezawa, K. Tohda, and S. Amemiya, Pure Appl. Chem. 72 (2000) 1851.

[9] A. M. James and A. Evans, Potentiometry and ion selective electrodes (Analytical Chemistry by open learning), John Willey and Sons Inc. (1987). 